
ISSN : 2615-1995, E-ISSN : 2615-0654

J. Madani., Vol. 2, No. 1, Maret 2019 (103 - 112)

(C)2018 Lembaga Kajian Demokrasi

MADANI

dan Pemberdayaan Masyarakat (LKD-PM)

\title{
PENGARUH PERPUTARAN KAS DAN PERPUTARAN PIUTANG TERHADAP PROFITABILITAS PT. INDOFOOD SUKSES MAKMUR TBK.
}

\author{
Febria Nurmawardi \\ Fakultas Ekonomi, Universitas Pamulang \\ febifebria@gmail.com \\ Iman Lubis \\ Fakultas Ekonomi, Universitas Pamulang \\ Dosen01479@unpam.ac.id
}

\begin{abstract}
Abstrak
Tujuan penulisan ini adalah untuk mengetahui perkembangan perputaran kas, perputaran piutang dan profitabilitas pada perusahaan PT. Indofood Sukses Makmur Tbk. Untuk mengetahui pengaruh perputaran kas dan perputaran piutang terhadap profitabilitas secara parsial dan simultan terhadap PT. Indofood Sukses Makmur Tbk. Data sekunder digunakan dalam penelitian ini berupa laporan keuangan perusahaan PT. Indofood Sukses Makmur Tbk tahun 2013-2017. Metode analisis yang digunakan adalah melakukan perhitungan pada variabel masing-masing, uji deskriptif, uji asumsi klasik, regresi linear berganda, uji $F$ dan uji $T$ yang bertujuan mendapatkan hasil pada variabel $X$ dan $Y$ apakah berpengaruh secara parsial maupun simultan. Berdasarkan hasil penelitian secara parsial, perputaran kas memiliki nilai Sig. 0,301 yang berarti tidak terdapat pengaruh antara perputaran kas terhadap profitabilitas. Perputaran piutang memiliki nilai Sig. 0,044 yang berarti bahwa perputaran piutang terdapat pengaruh terhadap profitabilitas. Dalam menguji hipotesis menggunakan Uji F diperoleh hasil nilai Sig. 0,038 sehingga variabel perputaran kas dan perputaran piutang secara simultan atau keseluruhan memiliki pengaruh terhadap profitabilitas.
\end{abstract}

Kata Kunci: Perputaran Kas, Perputaran Piutang, Profitabilitas.

\begin{abstract}
The purpose of this paper is to determine the development of cash turnover, accounts receivable turnover and profitability in the public company Indofood Sukses Makmur. To determine the effect of cash turnover and receivable turnover on profitability partially and simultaneously to the public company Indofood Sukses Makmur. Secondary data used in this study in the form of financial statements of the public company Indofood Sukses Makmur in 2013-2017. The analytical method used is to calculate each variable, descriptive test, classic assumption test, multiple linear regression, $F$ test and $T$ test which aims to get results on variables $X$ and $Y$ whether they have partially or simultaneous effect. Based on the results of the research partially, cash turnover has a probability about 0.301 which means there is no influence between cash turnover and profitability. Account receivable turnover has a probability about 0.044 which means that accounts receivable turnover has an influence on profitability. In testing the hypothesis using Test $F$ obtained the results of the probability about 0.038 so that the cash turnover variable and accounts receivable turnover simultaneously or overall have an influence on profitability.
\end{abstract}

Keyword: Cash Turnover, Receivable Turnover, Profitability

\section{PENDAHULUAN}

Setiap perusahaan pada dasarnya akan melakukan berbagai aktivitas untuk mencapai tujuan yang telah ditetapkan perusahaan yaitu mendapatkan laba, sehingga manajemen perusahaan selalu mencari jalan untuk dapat terus meningkatkan kinerja dan aktifitas perusahaan, salah satunya adalah memenuhi kebutuhan modal 
kerja yang cukup. Modal kerja yang biasa dikenal salah satunya adalah kas dan piutang. Perputaran kas adalah berapa kali perusahaan telah memutar kas selama periode pelaporan, yang dihitung dari omset tunai berdasarkan pendapatan perusahaan dibagi kas rata-rata selama periode tertentu. Menurut Kasmir (2015:140-141) Perputaran kas merupakan perbandingan antara penjualan dengan rata-rata kas, perputaran kas menunjukkan kemampuan kas dalam menghasilkan pendapatan sehingga dapat dilihat berapa kali uang kas berputar dalam satu periode tertentu. Semakin tinggi tingkat perputaran kas berarti semakin efisien tingkat penggunaan kasnya dan sebaliknya semakin rendah tingkat perputaranya semakin tidak efisien, karena semakin banyaknya uang yang berhenti atau tidak dipergunakan. Dengan demikian tingkat perputaran kas menunjukkan kecepatan kembalinya modal kerja yang tertanam pada kas atau setara kas menjadi kas kembali melalui penjualan atau pendapatan.

Kas diperlukan perusahaan baik untuk membiayai operasi perusahaan sehari-hari maupun untuk mengadakan investasi baru dalam aktiva tetap. Dalam mengukur tingkat perputaran kas, sumber masuknya kas yang telah tertanam dalam modal kerja adalah berasal dari aktivitas operasional perusahaan. Oleh karena itu, sumber kas dalam penelitian ini adalah berasal dari aktivitas penjualan. Makin tinggi tingkat perputaran kas berarti makin cepat kembalinya kas masuk pada perusahaan. Dengan demikian kas akan dapat dipergunakan kembali untuk membiayai kegiatan operasional sehingga tidak mengganggu kondisi keuangan perusahaan. Berdasarkan uraian mengenai perputaran kas diatas, dapat disimpulkan bahwa perputaran kas adalah perbandingan antara penjualan dengan rata-rata kas yang digambarkan dengan berapa kali kas dapat berputar dalam satu periodenya dalam tujuan untuk memperoleh keuntungan.

Tak hanya kas, dalam modal kerja di dunia usaha dikenal juga dengan piutang. Perputaran piutang adalah sebuah ukuran seberapa sering piutang usaha berubah menjadi kas atau seberapa cepat harta yang dihutangkan kepada pelanggan dapat kembali pada perusahaan. Menurut Bambang Riyanto, perputaran piutang merupakan tingkat perputaran piutang selama periode tertentu yang dapat diketahui dengan membagi jumlah penjualan selama periode tertentu dengan jumlah rata-rata piutang. Perusahaan dan para manajer sebagaimana juga para pemakai eksternal informasi keuangan perlu mengukur seberapa efisien perusahaan menggunakan piutang. Jadi, sangatlah penting untuk mempertahankan kredit bersih dalam kurun waktu terikatnya rata-rata pengumpulan pi- utang. Piutang merupakan salah satu unsur dari aktiva lancar dalam neraca perusahaan yang timbul akibat adanya penjualan barang dan jasa atau pemberian kredit terhadap debitur yang pembayaran pada umumnya diberikan dalam tempo 30 hari (tiga puluh hari) sampai dengan 90 hari (sembilan puluh hari). Dalam arti luas, piutang merupakan tuntutan terhadap pihak lain yang berupa uang, barang, atau jasa yang dijual secara kredit.

Perputaran piutang ini akan dibahas untuk mengetahui bagaimana perputaran piutang tersebut. Menurut Kasmir (2015:176) Perputaran Piutang merupakan rasio yang digunakan untuk mengukur berapa lama penagihan piutang selama satu periode atau berapa kali dana yang ditanam dalam piutang ini berputar dalam satu periode. Adapun pendapat lain, Menurut Wibowo (2014) Perputaran piutang merupakan suatu angka yang menunjukkan berapa kali suatu perusahaan melakukan tagihan atas piutangnya pada suatu periode tertentu, angka ini diperoleh dengan membandingkan penjualan dengan piutang rata-rata. Berdasarkan uraian diatas maka dapat disimpulkan bahwa perputaran piutang merupakan rasio yang digunakan dalam mengukur berapa banyak piutang itu berputar setiap periodenya dengan menggunakan perbandingan penjualan dengan piutang rata-rata sebagai rumus untuk menghitung perputaran piutang tersebut.

Pada umumnya suatu perusahaan didirikan dengan tujuan untuk memperoleh laba. Laba merupakan hasil yang menguntungkan atas usaha yang dilakukan perusahaan pada suatu periode tertentu. Dengan laba ini dapat digunakan perusahaan untuk tambahan pembiayaan dalam menjalankan operasional perusahaan, dan yang terpenting adalah sebagai alat untuk menjaga kelangsungan hidup perusahaan. Besar atau kecilnya laba yang dihasilkan perusahaan tergantung kepada kemampuan perusahaan dalam mengelola aktiva yang dimiliki oleh perusahaan. Semakin baik pengelolaan aktiva yang dimiliki, maka akan semakin optimal laba yang akan dihasilkan oeh perusahaan. Menurut Adad Danuarta (2014) Profitabilitas merupakan tujuan akhir yang ingin dicapai suatu perusahaan yaitu memperoleh laba atau keuntungan yang maksimal, di samping hal-hal lainnya. Dalam hal ini, sumbersumber yang dimiliki perusahaan menjadi peran penting untuk menghasilkan keuntungan dengan maksimal. Berdasarkan pengertian para ahli, maka dapat ditarik kesimpulan bahwa profitabilitas merupakan hasil bersih dari berbagai kebijakan dan keputusan manajemen, dan rasio profitabilitas akan menunjukkan tentang efektivitas pengelolaan perusahaan oleh manajemen.

Berdasarkan uraian tersebut terdapat po- 
tensi bahwa peran perputaran kas dan perputaran piutang sebagai mekanisme yang dapat mempengaruhi profitabilitas yang bertujuan untuk meningkatkan keuntungan perusahaan. Peneliitian ini mengacu pada penelitian Arum Puji Tri Lestari (2017) yang bertujuan untuk menguji perputaran kas dan perputaran piutang terhadap profitabilitas perusahaan. Penelitian ini menggunakan periode waktu yang lebih lama yaitu lima tahun sehingga penelitian ini akan memberikan empiris yang berbeda dengan penelitian sebelumnya.

\section{Kajian Pustaka \\ Perputaran Kas}

Perputaran kas adalah berapa kali perusahaan telah memutar kas selama periode pelaporan, yang dihitung dari omset tunai berdasarkan pendapatan perusahaan dibagi saldo kas rata-rata selama periode tersebut. Menurut Teguh Pudjo Mulyono, Perputaran kas dimulai saat kas diinvestasikan ke dalam kredit yang disalurkan sampai pada saat kembali lagi menjadi kas yang tepat dan tidak terlambat. Tingkat perputaran kas merupakan ukuran efesiensi penggunaan kas yang dilakukan oleh perusahaan karena tingkat perputaran kas menggambarkan kecepatan arus kas kembalinya kas yang telah ditanamkan didalam modal kerja.

Menurut Bambang Riyanto (2011 : 95) bahwa Perputaran kas adalah perbandingan antara penjualan dengan jumlah kas rata-rata. Jumlah kas dapat pula dihubungkan dengan jumlah penjualan atau salesnya. Perbandingan antara sales dengan jumlah kas rata-rata menggambarkan tingkat perputaran kas (cash turnover). Menurut Wild, Subramanyan dan Haley (2005:42) bahwa Perputaran kas dalam satu periode dapat dihitung dengan rumus : Perputaran Kas $=($ Penjualan bersih) $/($ Rata-rata kas $) \times 1$.

Semakin tinggi tingkat perputaran kas berarti semakin cepat kembalinya kas masuk pada perusahaan. Dengan demikian kas akan dapat dipergunakan kembali untuk membiayai kegiatan operasional sehingga tidak mengganggu kondisi keuangan perusahaan. Kas adalah harta lancar yang sangat penting yang merupakan alat pertukaran dan juga dipakai sebagai alat pengukur dalam akuntansi atau dalam dunia perekonomian.

\section{Perputaran Piutang}

Perputaran piutang (inventory turn over) merupakan salah satu rasio aktivitas yang menunjukkan berapa kali dana yang diinvestasikan dalam piutang berputar dalam satu periode. Riyanto dalam Bramasto (2007) menyatakan bahwa, perputaran piutang merupakan rasio yang menunjukkan lamanya waktu untuk mengubah piutang menjadi kas. Piutang merupakan salah satu komponen modal kerja. Piutang merupakan tagihan perusahaan kepada pihak lainnya yang memiliki jangka waktu tidak lebih dari satu tahun yang timbul akibat adanya penjualan barang atau jasa secara kredit atau angsuran. Semakin tinggi rasio perputaran piutang, menunjukkan kondisi perusahaan semakin baik, karena modal kerja yang ditanamkan dalam piutang semakin rendah. Sebaliknya, semakin rendah rasio perputaran piutang, menunjukkan kondisi perusahaan yang kurang baik, karena adanya over investment dalam piutang.

MenurutS.Fradina (2016) piutang (receivable) merupakan salah satu jenis transaksi akuntansi yang mengurusi penagihan konsumen yang berhutang pada seseorang, suatu perusahaan, atau suatu organisasi untuk barang dan layanan yang telah diberikan pada konsumen tersebut. Piutang biasanya memiliki bagian yang signifikan dari total aset lancar perusahaan. Berdasarkan definisi piutang, maka dapat disimpulkan bahwa piutang merupakan harta perusahaan atau koperasi yang timbul karena terjadinya transaksi penjualan secara kredit atas barang dan jasa yang dihasilkan oleh perusahaan.

\section{Profitabilitas}

Dikutip dalam Akutansi pedia (2017) Rasio profitabilitas digunakan untuk mengukur seberapa menguntungkan perusahaan. Tujuan didirikannya perusahaan adalah untuk memperoleh profit karenanya rasio profitabilitas menjadi ukuran utama tentang performa sebuah perusahaan. Apakah Laba yang besar saja sudah cukup. Sebelum mengambil keputusan seorang manajer keuangan harus mengetahui terlebih dahulu bagaimana kondisi keuangan perusahaan saat itu. Kondisi keuangan perusahaan yang disajikan dalam bentuk laporan keuangan dapat dijadikan pertimbangan manajer keuangan dengan melakukan analisis terlebih dahulu terhadap laporan keuangan tersebut.

Tingkat profitabilitas yang tinggi pada sebuah perusahaan akan meningkatkan daya saing antar perusahaan. Perusahaan yang memperoleh tingkat keuntungan yang tinggi akan mampu membuka cabang yang baru serta memperluas usahanya dengan membuka investasi baru yang terkait dengan perusahaan induknya. Tingkat keuntungan yang tinggi menandakan pertumbuhan perusahaan pada masa mendatang. Profitabilitas dinilai sangat penting, karena untuk melangsungkan hidup suatu perusahaan haruslah berada dalam keadaan menguntungkan atau profitable. Tanpa keuntungan maka sulit bagi perusahaan untuk menarik modal dari luar. Profitabilitas suatu perusahaan menunjukkan per- 
bandingan antara laba dengan aktiva atau modal yang menghasilkan laba tersebut.

\section{METODE}

\section{Definisi Operasional}

Definisi operasional variabel adalah penelitian atau pembatasan yang digunakan untuk mengatur hubungan dua variabel atau lebih dalam hipotesis dan akan dilaksanakan setelah masing-masing variabel.

1. Perputaran Kas $\left(\mathrm{X}_{1}\right)$

Perputaran kas adalah berapa kali perusahaan telah memutar kas selama periode tertentu. Perputaran kas berfungsi untuk mengukur tingkat kecukupan modal kerja perusahaan yang dibutuhkan untuk membayar tagihan dan membiayai penjualan. Artinya untuk mengukur tingkat ketersediaan kas untuk membayar tagihan (utang) dan biayabiaya yang berkaitan dengan penjualan.

Perputaran Kas $=$ Penjualan $:$ Rata-Rata Kas

2. Perputaran piutang $\left(\mathrm{X}_{2}\right)$.

Perputaran piutang adalah suatu ukuran yang menunjukkan berapa kali suatu piutang perusahaan telah diputar kembali menjadi kas frekuensi perputaran piutang tersebut dinyatakan dalam setiap kali berputar per tahun. Dalam penelitian perputaran piutang dihitung dengan rumus sebagai berikut : Perputaran Piutang $=$ Penjualan $:$ Rata-Rata Piutang.

3. Profitabilitas (Y)

Profitabilitas adalah kemampuan perusahaan dalam memperoleh laba atau suatau ukuran dalam presentase yang digunakan untuk menilai sejauh mana perusahaan mampu menghasilkan laba pada tingkat yang diterima. Tingkat profitabilitas diukur dengan return on asset (ROA) yang merupakan kemampuan dari modal yang diinvestasikan dalam keseluruhan aktiva untuk menghasilkan keuntungan. Dalam penelitian profitabilitas dihitung dengan rumus ROA (return on asset) sebagai berikut: Return On Asset = Laba Sebelum Pajak: Total Aktiva x 100\%.

\section{Populasi, Sampel, Jenis dan Sumber Data}

Populasi untuk penelitian ini menggunakan data-data perusahaan PT. Indofood Sukses Makmur Tbk, yang bersumber dari data sekunder, diperoleh dari laporan keuangan perusahaan pada perusahaan PT. Indofood Sukses Makmur Tbk. Penelitian ini menggunakan data sekunder dengan pendekatan kuantitatif yang diperoleh dari laporan keuangan perusahaan pada perusahaan PT. Indofood Sukses Makmur Tbk. Sampel yang akan digunakan dalam penelitian ini adalah perusahaan PT. Indofood Sukses Makmur Tbk selama 5 tahun, yaitu mulai dari periode 2013 sampai dengan 2017.

\section{Teknik Pengambilan Sampel}

Dalam penelitian ini menggunakan teknik pengambilan sampel purposive sampling method, yaitu teknik pemilihan sampel dengan cara menetapkan berdasarkan beberapa kriteria sampel tertentu yang disesuaikan dengan tujuan penelitian. Adapun kriteria yang ditetapkan, yaitu :

1. Perusahaan PT. Indofood Sukses Makmur Tbk dengan periode pengamatan yaitu tahun 2013 sampai 2017.

2. Perusahaan yang memiliki data laporan keuangan yang lengkap selama periode penelitian pada tahun 2013 sampai 2017.

3. Menerbitkan Laporan keuangan yang berakhir per 31 Desember (tahun 2013 sampai 2017).

\section{Teknik Analisis Data}

1. Menentukan sampel penelitian.

2. Mengumpulkan data laporan keuangan mulai tahun 2013-2017.

3. Melakukan perhitungan pada masingmasing variabel.

4. Melakukan Uji Deskriptif Asosiatif. Uji Deskriptif asosiatif adalah analisis yang bertujuan untuk memberikan gambaran mengenai suatu data agar data yang tersaji menjadi mudah dipahami dan informatif bagi orang yang membacanya. Statistika deskriptif menjelaskan berbagai karakteristik data seperti rata-rata (mean), jumlah (sum), simpangan baku (Std. Deviation), varians (Variance), nilai minimum (minimum), dan nilai maksimum (Maximum). Kemudian melakukan uji atas pengaruh satu variabel dengan variabel lain.

5. Melakukan Uji Korelasi. Uji Korelasi adalah uji yang digunakan untuk mempelajari hubungan antara dua variabel atau lebih. $\mathrm{Hu}-$ bungan yang dipelajari adalah hubungan yang linier atau garis lurus. Ada dua jenis uji korelasi, yaitu Korelasi Pearson dan Korelasi Spearman. Bila data berdistribusi normal atau mendekati normal, maka Korelasi Pearson menjadi pilihan, tetapi bila distribusi data sangat ekstrem tidak normal, maka Korelasi Spearman jadi pilihan.

Ukuran korelasi disebut koefisien korelasi, disingkat dengan $r$. Nilai $r$ berkisar antara -1 sampai +1 , termasuk 0 . Semakin besar nilai $r$ (mendekati angka 1), maka semakin erat hubungan kedua variabel tersebut. Sebaliknya, semakin kecil nilai korelasi (mendekati angka 0), maka semakin lemah hubungan kedua variabel tersebut. Perlu diketahui bahwa kendatipun nilai $r$ 
besar, yang menunjukkan ada hubungan yang erat, tetapi kita tidak dapat serta merta menyatakan bahwa hubungan yang terjadi adalah hubungan sebab-akibat antara dua variabel tersebut.

Nilai $r$ ini bisa bertanda positif, tetapi juga bisa negatif. Berikut adalah interpretasi dari tanda pada koefisien korelasi.

a. Jika nilai $r=+$ (positif), maka hubungannya adalah berbanding lurus. Artinya, semakin besar nilai variabel $\mathrm{X}$, maka semakin besar pula nilai variabel $\mathrm{Y}$ atau semakin kecil nilai variabel $\mathrm{X}$ maka semakin kecil pula nilai variabel $\mathrm{Y}$.

b. Jika nilai $r=-$ (negatif) maka hubungannya adalah berbanding terbalik. Artinya semakin besar nilai variabel $\mathrm{X}$, maka semakin kecil nilai variabel $\mathrm{Y}$ atau semakin kecil nilai variabel $\mathrm{X}$, maka semakin besar nilai variabel $Y$.

c. Jika nilai $\mathrm{r}=0$, artinya tidak ada hubungan sama sekali antara variabel $\mathrm{X}$ dan variabel Y

6. Uji Asumsi Klasik

Uji asumsi klasik dalam penelitian ini adalah sebagai berikut:

a. Uji Normalitas. Uji normalitas merupakan syarat dalam penelitian kuantitatif sebagai bukti empiris, bahwa karakteristik sampel dengan karakteristik populasi. Uji normalitas dalam penelitian ini bertujuan untuk mengetahui apakah variabel dependen dan independen berdistribusi normal atau tidak (Sahid Raharjo :2017). Uji yang digunakan dalam penelitian ini adalah dengan metode Uji Kolmogorov-Smirnov (Uji K-S). Uji K-S dilakukan untuk membuat hipotesis:

i. Ho : Data tidak berdistribusi normal apabila nilai signifikansi $<5 \%$

ii. Ha : Data berdistribusi normal apabila nilai signifikansi $>5 \%$

b. Uji Autokorelasi. Uji Autokorelasi merupakan bagian dari uji asumsi klasik dalam analisis regresi linier untuk data runtut waktu. Uji Asumsi klasik dimaknai sebagai syarat yang harus dipenuhi sebelum dilakukannya analisis regresi linier. Model regresi yang baik tidak terdapat masalah autokorelasi. (Sahid Raharjo :2017). Autokorelasi muncul karena observasi yang berurutan sepanjang waktu berkaitan satu sama lain. Pengujian autokorelasi dapat dilakukan dengan metode uji run test.

c. Uji Multikolinearitas. Uji multikolinearitas merupakan bagian dari uji asumsi klasik dalam analisis regresi linier. Uji multikolinearitas bertujuan untuk mengetahui apakah terjadi hubungan yang kuat antar variable independent. Model regresi yang baik ditandai dengan tidak terjadi interkorelasi antar variable independent (tidak terjadi gejala multikolinearitas) (Sahid Raharjo : 2017). Salah satu cara yang paling akurat untuk mendeteksi ada atau tidaknya gejala multikolinearitas ini adalah dengan menggunakan metode Tolerance dan VIF (Variance Inflation Factor). Uji multikolinearitas dapat dilakukan dengan pengujian sebagai berikut:

Jika nilai Tolerance $>0,10$ dan VIF $<0,10$, maka dapat disimpulkan tidak terjadi multikolinearitas. 2. Jika nilai Tolerance $<0,10$ dan VIF $>0,10$, maka dapat disimpulkan bahwa terjadi multikolinearitas (Ghozali, 2011:106). Nilai VIF dapat dihitung menggunakan rumus : $\mathrm{VIF}=(-)$

Keterangan :

VIF = Variance Inflation Factor

R2 = koefisisen determinasi

d. Uji Heteroskedastisitas. Uji heteroskedastisitas merupakan bagian dari uji asumsi klasik dalam analisis regresi linier, dimana menjadi salah satu syarat yang harus dipenuhi dalam model regresi yang baik adalah tidak terjadi gejala heteroskedastisitas. Dan bila terjadi gejala heteroskedastisitas akan berakibat pada sebuah keraguan (ketidakakuratan) pada suatu hasil regresi yang dilakukan. Ada tidaknya heteroskedastisitas dapat dilakukan dengan uji glejser.

7. Uji Analisis Regresi Linier Berganda

Analisis regresi linear berganda dalam penelitian ini digunakan untuk menghitung besarnya pengaruh variabel independen perputaran kas, dan perputaran piutang terhadap variabel dependen profitabilitas (yang diukur dengan menggunakan return on asset (ROA). Dengan kata lain melibatkan tiga variabel bebas $\left(\mathrm{X}_{1}, \mathrm{X}_{2}\right)$ dan satu variabel terikat (Y). Adapun bentuk model yang akan diuji dalam penelitian ini yaitu : Mencari persamaan regresi untuk tiga preditor Adapun persamaan model regresi linear (Suharyadi dan Purwanto 2011:210) adalah: $\mathrm{Y}=\mathrm{a}+\mathrm{b}_{1} \mathrm{X}_{1}+\mathrm{b}_{2} \mathrm{X}_{2}+\ldots+\mathrm{bk} \mathrm{Xk}$ Keterangan:

$\begin{array}{ll}\mathrm{Y} & : \text { nilai prediksi dari } \mathrm{Y} \\ \mathrm{a} & : \text { bilangan konstanta } \\ \mathrm{b}_{1}, \mathrm{~b}_{2} \ldots, \mathrm{bk}, \mathrm{Xk} & : \text { koefisien variabel bebas } \\ \mathrm{X}_{1}, \mathrm{X}_{2} & : \text { variabel independent } \\ \mathrm{X}_{1} & : \text { Perputaran Kas }\end{array}$


$\mathrm{X}_{2} \quad$ : Perputaran Piutang

Model regresii dalam penelitian ini dinayatakan sebagai berikut:

$\mathrm{P}(\mathrm{Y})=\mathrm{a}+\mathrm{b}_{1}(\mathrm{PK})+\mathrm{b}_{2}(\mathrm{PP})$

$$
\begin{array}{ll}
\mathrm{P} & : \text { Profitabilitas } \\
\mathrm{b}_{1}, \mathrm{~b}_{2} & \text { : Koefisien Regresi } \\
\mathrm{a} & \text { : Konstanta }
\end{array}
$$

Mendeteksi variabel X dan Y yang akan dimasukkan pada analisis regresi linear berganda dengan bantuan software sesuai dengan perkembangan yang ada yaitu SPSS yang akan menunjukkan uji simultan (bersamasama), dalam arti variabel $\mathrm{X} 1, \mathrm{X} 2$ secara bersama-sama mempengaruhi terhadap Y.

8. Melakukan Pengujian Hipotesis (Uji t dan Uji f)

Metode ini dilakukan dengan cara memasukkan semua variabel secara bersamasama dan pada setiap saat dilakukan pembuangan terhadap variable yang tidak signifikan sampai diperoleh model regresi yang paling baik.

a. Uji parsial (uji t)

Bertujuan untuk mengetahui apakah variabel bebas secara parsial dimasukkan ke dalam model akan mempunyai pengaruh signifikan terhadap variabel terikatnya.

Langkah-langkah pengujian adalah sebagai berikut :

i. Untuk mengukur pengaruh tingkat perputaran kas terhadap profitabilitas pada perusahaan PT. Indofood Sukses Makmur Tbk, maka disusun hipotesis statistik sebagai berikut:

$\mathrm{H}_{0} \cdot{ }^{1}$ : Tingkat perputaran kas tidak berpengaruh terhadap Profitabilitas pada perusahaan PT. Indofood Sukses Makmur Tbk.

$\mathrm{H}_{1 .}{ }^{1}$ : Tingkat perputaran kas berpengaruh terhadap Profitabilitas pada perusahaan PT. Indofood Sukses Makmur Tbk.

ii. Untuk mengukur pengaruh tingkat perputaran piutang terhadap profitabilitas pada perusahaan PT. Indofood Sukses Makmur Tbk, maka disusun hipotesis statistik sebagai berikut:

$\mathrm{H}_{0}{ }^{2}$ : Tingkat perputaran piutang tidak berpengaruh terhadap Profitabilitas pada perusahaan PT. Indofood Sukses Makmur Tbk.

$\mathrm{H}_{1} \cdot{ }^{2}$ : Tingkat perputaran piutang berpengaruh terhadap Profitabilitas pada perusahaan PT. Indofood Sukses Makmur Tbk. b. Uji Model (Uji F)

Uji statistik F pada dasarnya digunakan untuk menguji model regresi bukan sebagai pengujian secara simultan. Dasar pengambilan keputusan menggunakan angka signifikansi adalah sebagai berikut:

i. Jika nilai signifikan $\mathrm{F} \geq 0.05$, maka hipotesis nol $\left(\mathrm{H}_{0}\right)$ ditolak. Maka model regresi dikatakan tidak fit atau tidak baik.

ii. Jika nilai signifikan $\mathrm{F}<0.05$, maka hipotesis satu $\left(\mathrm{H}_{1}\right)$ diterima. Maka model dapat dikatakan fit atau baik.

c. Koefisien determinasi $\left(\mathrm{R}^{2}\right)$

Koefisien determinasi $\left(\mathrm{R}^{2}\right)$ digunakan untuk mengetahui seberapa besar hubungan dari beberapa variable dalam pengertian yang lebih jelas. Pada intinya mengukur seberapa jauh kemampuan model dalam menerangkan variasi variabel dependen, dengan kata lain koefisien determinasi digunakan untuk mengetahui seberapa besar variabel bebas bisa menjelaskan variabel terkait. Nilai koefisien determinasi adalah antara nol dan satu. Nilai $R^{2}$ yang kecil berarti variabel-variabel independen dalam menjelaskan variasi variabel dependen amat terbatas. Jika koefesien determinasi semakin mendekati nol maka semakin kecil pengaruh semua variabel bebas terhadap nilai variabel terikat. Sebaliknya, jika koefisien determinasi semakin mendekati angka satu maka semakin besar pengaruh semua variabel bebas terhadap nilai variabel terikat (Sahid

\begin{tabular}{|c|c|c|c|c|}
\hline \multicolumn{5}{|c|}{$\begin{array}{l}\text { Tabel 1. Parameter Regresi Berganda } \\
\text { Perputaran Kas dan Perputaran Piutang terhadap } \\
\text { Profitabilitas PT. Indofood Sukses Makmur Tbk }\end{array}$} \\
\hline \multicolumn{5}{|c|}{ Coefficients $^{a}$} \\
\hline \multirow{2}{*}{\multicolumn{2}{|c|}{ Model }} & \multicolumn{2}{|c|}{ Unstandardized Coefficients } & \multirow{2}{*}{$\begin{array}{c}\text { Standardized } \\
\text { Coefficients } \\
\text { Beta }\end{array}$} \\
\hline & & B & Std. Error & \\
\hline \multirow[t]{3}{*}{1} & (Constant) & .244 & .072 & \\
\hline & Perputaran Kas $\left(\mathrm{X}_{1}\right)$ & .040 & .029 & .389 \\
\hline & Perputaran Piurang $\left(X_{2}\right)$ & -.026 & .006 & -1.301 \\
\hline \multicolumn{5}{|c|}{ a. Dependent Variable: Profitabilitas $(\mathrm{Y})$} \\
\hline \multicolumn{5}{|c|}{ Sumber: Olahan Sendiri } \\
\hline
\end{tabular}
Raharjo : 2017).

\section{HASIL dan PEMBAHASAN}

Dalam penelitian ini peneliti telah mencari hubungan perputaran kas dan perputaran piutang dengan profitabilitas. Hasilnya menunjukkan bahwa perputaran kas memiliki hubungan 
searah dengan profitabilitas sebesar $74,5 \%$ dan perputaran piutang memiliki hubungan berbanding terbalik dengan profitabilitas 96,2\% . Hal ini disebabkan karena diperoleh perputaran kas dan perputaran piutang yang meningkat dan profitabilitas juga meningkat. Namun, antara perputaran kas dan perputaran piutang memiliki hubungan searah sebesar $87,2 \%$,

Hasil pengujian secara parsial perputaran kas dengan tingkat signifikansi sebesar 0,301 > 0.05 artinya tidak berpengaruh signifikan terhadap profitabilitas. Dengan demikian hasil hipotesis pertama yang menyebutkan bahwa "Perputaran kas tidak berpengaruh terhadap profitabilitas pada Perusahaan PT. Indofood Sukses Makmur Tbk, tahun 2013-2017". Perputaran kas yang makin tinggi akan semakin baik, karena ini menunjukkan semakin efisiensi didalam penggunaan kas tetapi Perputaran kas yang berlebihan dengan modal kerja yang tersedia terlalu kecil, akan mengakibatkan kurang dapat memenuhi kebutuhan perusahaan. Demikian pula sebaliknya, dengan makin rendahnya perputaran kas mengakibatkan banyaknya uang kas yang tidak produktif sehingga akan mengurangi profitabilitas perusahaan. Penelitian kali ini menunjukkan bahwa perputaran kas tidak terdapat pengaruh terhadap profitabilitas. Penelitian yang dilakukan ini tidak konsisten dengan penelitian sebelumnya yang dilakukan Novia Ingrid Pangalila (2017) yaitu "Perputaran Kas mempunyai pengaruh terhadap Profitabilitas".

Hasil pengujian secara parsial perputaran piutang dengan tingkat signifikansi $0.044<$ 0,05 artinya berpengaruh signifikan pada profitabilitas. Dengan demikian hipotesis kedua yang menyebutkan bahwa "Perputaran piutang berpengaruh terhadap profitabilitas pada Perusahaan Perusahaan PT. Indofood Sukses Makmur Tbk, tahun 2013-2017" maka hipotesis ini dengan kesimpulan perputaran piutang berpengaruh signifikan terhadap profitabilitas. Perputaran piutang menunjukkan berapa kali suatu perusahaan menagih piutangnya dalam satu periode atau kemampuan dana yang tertanam dalam piutang berputar dalam suatu periode tertentu. Makin besarnya jumlah perputaran piutang berarti semakin besar resiko, tetapi bersamaan dengan itu juga akan memperbesar profitabilitas. Piutang merupakan aktiva lancar, dimana dalam menentukan jumlah atau tingkat aktiva lancar pihak manejemen harus mempertimbangkan keuntungan dan kelebihan antara profitabilitas dan risiko. Oleh karena itu jika sebuah perusahaan dapat mengelola aktiva lancarnya dengan lebih efisien sehingga beroperasi dengan investasi yang lebih kecil pada modal kerja, maka hal ini akan meningkatkan profitabilitas. Maka semakin tinggi tingkat perputaran piutang, semakin cepat dana yang dialokasikan dalam piutang kembali menjadi kas maka akan berpengaruh terhadap profitabilitas atau keuntungan perusahaan. Penelitian yang dilakukan ini konsisten dengan penelitian sebelumnya yang dilakukan Matilde Amaral (2017) yaitu "Perputaran piutang mempunyai pengaruh pada profitabilitas".

Dalam penelitian ini peneliti telah menguji secara simultan pengaruh perputaran kas dan perputaran piutang pada profitabilitas. Hasilnya menunjukkan bahwa secara simultan perputaran kas dan perputaran piutang memiliki pengaruh terhadap terhadap profitabilitas. Hal ini disebabkan karena diperoleh nilai Signifikansi $0.038<0,05$. Selain itu, hal yang menyebabkan perputaran kas dan perputaran piutang memiliki pengaruh terhadap profitabilitas yaitu dikarenakan perputaran kas yang dimililiki perusahaan cukup besar atau dikatakan perpuataran kas-nya diatas rata-rata, sehingga perusahaan dapat memenuhi kewajiban jangka pendeknya. Hasil penelitian ini konsisten dengan penelitian Nurri Lestari (2017) yaitu "Perputaran kas dan perputaran piutang secara simultan berpengaruh terhadap profitabilitas" dengan judul penelitian "Pengaruh Perputaran Kas, perputaran piutang dan persediaan terhadap profitabilitas pada Perusahaan Sub-Sektor makanan dan minuman yang terdaftar di BEI.

Hasil Uji Asumsi Klasik

Uji asumsi klasik dari masing-masing model adalah sebagai berikut :

\section{Uji Normalitas}

\begin{tabular}{|c|c|c|}
\hline \multicolumn{3}{|c|}{$\begin{array}{l}\text { Tabel 2. Uji Normalitas } \\
\text { Perputaran Kas dan Perputaran Piutang terhadap } \\
\text { Profitabilitas PT. Indofood Sukses Makmur Tbk }\end{array}$} \\
\hline \multicolumn{3}{|c|}{ One-Sample Kolmogorov-Smirnov Test } \\
\hline & & $\begin{array}{l}\text { Unstandardized } \\
\text { Residual }\end{array}$ \\
\hline \multicolumn{2}{|l|}{$\mathrm{N}$} & 5 \\
\hline Normal & Mean & .0000000 \\
\hline Parameters $\mathrm{s}^{\mathrm{a}, \mathrm{B}}$ & Std. Deviation & 1.17047039 \\
\hline Most Extreme & Absolute & .146 \\
\hline \multirow[t]{2}{*}{ Differences } & Positive & .146 \\
\hline & Negative & -.132 \\
\hline \multicolumn{2}{|l|}{ Kolmogorov-Smirnov Z } & .327 \\
\hline \multicolumn{2}{|l|}{ Asymp. Sig. (2-Tailed) } & 1.000 \\
\hline \multicolumn{3}{|l|}{$\begin{array}{l}\text { A. Test Distribution Is Normal. } \\
\text { B. Calculated From Data. }\end{array}$} \\
\hline & & er: Olahan Sendiri \\
\hline
\end{tabular}

Uji Normalitas adalah uji yang dimaksudkan untuk mendeteksi apakah nilai residual setiap model regresi berdistribusi normal, penelitian ini menggunakkan alat uji Kolmogorov-Smirnov 
dan dapat dilakukan dengan melihat normal probability plot dan histogram. Berdasarkan hasil output Uji Normalitas, diketahui nilai signifikansi $1,000>0,05$. Dasar pengambilan keputusan pada Uji normalitas adalah Jika nilai signifikansi $>0,05$ maka data tersebut berdistribusi normal.

\section{Uji Autokorelasi}

Uji Autokorelasi merupakan bagian dari uji asumsi klasik dalam analisis regresi linear. Uji Asumsi klasik dimaknai sebagai syarat yang harus dipenuhi sebelum dilakukannya analisis regresi linear. Model regresi yang baik tidak terdapat masalah autokorelasi. Uji yang digunakan dalam uji autokorelasii ini dalah run test, Berdasarkan hasil output Uji Normalitas diatas, diketahui nilai signifikansi 1,000 >0,05. Dasar pengambilan keputusan pada Uji normalitas adalah Jika nilai signifikansi $>0,05$ maka data tersebut berdistribusi normal. Sebaliknya jika nilai signifikansi $<0,05$ maka data tersebut berdistribusi tidak normal, maka dapat disimpulkan bahwa nilai residual berdistribusi normal karena lebih dari 0,05.

\section{Uji Multikolinieritas}

\begin{tabular}{|c|c|}
\hline $\begin{array}{c}\text { Tabel 3. Uji Multikolineritas } \\
\text { Perputaran Kas dan Perputaran Piutang terhadap } \\
\text { Profitabilitas PT. Indofood Sukses Makmur Tbk }\end{array}$ \\
\hline \multicolumn{2}{|c|}{ Collinearity Statistics } \\
\hline Tolerance & VIF \\
\hline .240 & 4.169 \\
\hline .240 & 4.169 \\
\hline
\end{tabular}

Uji multikolinearitas dimaksudkan untuk menguji apakah dalam suatu model regresi ditemukan adanya korelasi antar variabel bebas yang satu dengan yang lainnya. Untuk mendeteksi adanya multikolinieritas dapat dilihat dari nilai VIF dan tolerance. Multikolinieritas terjadi apabila nilai VIF lebih dari 10 dengan nilai tolerance kurang dari 0,1 . Jadi dikatakan tidak terjadi multikolinieritas apabila nilai VIF kurang dari 10 dan nilai tolerance lebih dari 0,1. Pada model 1 maupun model 2 diketahui nilai tolerance lebih dari 0,1 dan nilai VIF kurang dari 10, Sehingga dapat disimpulkan model regresi 1 maupun model 2 bebas dari multikolinieritas dan data layak digunakan dalam model regresi. Berdasarkan hasil output Uji Multikolinearitas, diketahui nilai Tolerance $0,240>0,10$, dan nilai VIF $4,169<10,00$. Dasar pengambilan keputusan pada Uji Multikolinearitas adalah Jika nilai Tolerance $>0,10$ maka artinya tidak terjadi multikolinearitas terhadap data yang di uji, dan melihat nilai VIF Jika $<10,00$ maka artinya tidak terjadi multikolinearitas terhadap data yang di uji dan sebaliknya, maka dapat disimpulkan bahwa data yang di uji tidak terjadi multikolinearitas.

\section{Uji Heteroskedastisitas}

\begin{tabular}{|c|c|c|c|c|c|c|}
\hline \multicolumn{7}{|c|}{$\begin{array}{l}\text { Tabel 4. Uji Heteroskedastisitas } \\
\text { Perputaran Kas dan Perputaran Piutang terhadap } \\
\text { Profitabilitas PT. Indofood Sukses Makmur Tbk }\end{array}$} \\
\hline \multicolumn{7}{|c|}{ Coefficients $^{\mathrm{a}}$} \\
\hline \multirow{2}{*}{\multicolumn{2}{|c|}{ Model }} & \multicolumn{2}{|c|}{$\begin{array}{l}\text { Unstandardized } \\
\text { Coefficients }\end{array}$} & \multirow{2}{*}{$\begin{array}{c}\text { Standardized } \\
\text { Coefficients } \\
\text { Beta }\end{array}$} & \multirow[b]{2}{*}{$t$} & \multirow[b]{2}{*}{ Sig. } \\
\hline & & B & $\begin{array}{l}\text { Std. } \\
\text { Error }\end{array}$ & & & \\
\hline \multirow[t]{3}{*}{1} & (Constant) & .024 & .033 & & .728 & .542 \\
\hline & Perputaran Kas $\left(X_{1}\right)$ & .010 & .013 & .904 & .735 & .539 \\
\hline & Perputaran Piurang $\left(X_{2}\right)$ & .002 & .003 & 1.069 & .869 & .476 \\
\hline \multicolumn{7}{|c|}{ a. Dependent Variable: Abs-Res } \\
\hline & & & & \multicolumn{3}{|c|}{ Sumber: Olahan Sendiri } \\
\hline
\end{tabular}

Berdasarkan hasil output Uji heteroskedastisitas, diketahui nilai signifikansi (Sig) antara variable independent dengan absolut residual lebih $>0,05$ yaitu untuk perputaran kas 0,539 dan untuk perputaran piutang $>0,05$ yaitu 0,476 . Dasar pengambilan keputusan uji heteroskedastisitas adalah jika nilai Signifikansi > 0,05 artinya tidak terjadi heteroskedastisitas dan sebaliknya jika nilai signifikansi $<0,05$ artinya terjadi heteroskedastisitas. maka dapat disimpulkan bahwa tidak terjadi heteroskedastisitas antara perputaran kas dan tidak terjadi heteroskedastisitas antara perputaran piut ang.

\section{Uji Hipotesis}

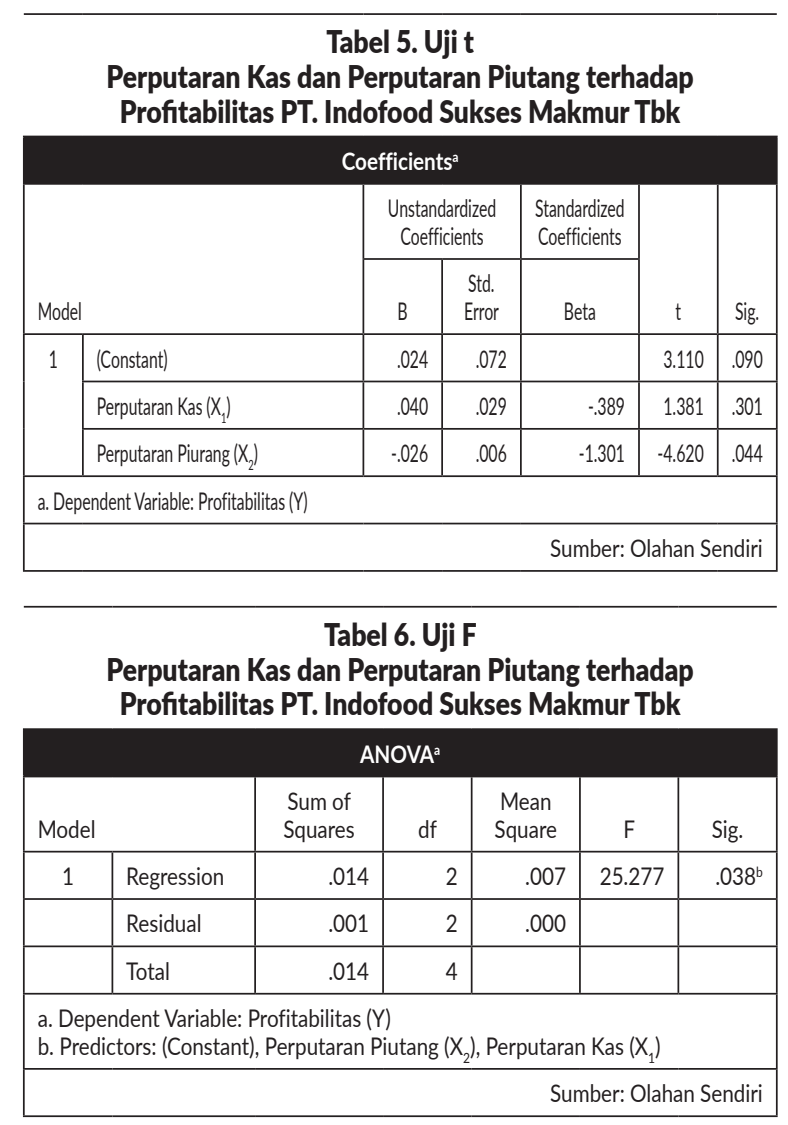




\section{Pengujian hipotesis pertama $\left(\mathrm{H}_{1}\right)$}

Berdasarkan hasil output Uji t, diketahui nilai Sig. untuk pengaruh perputaran kas $\left(\mathrm{X}_{1}\right)$ terhadap profitabilitas $(\mathrm{Y})$ adalah sebesar $0,301>0.05$. Dasar pengambilan keputusan Uji t Parsial dalam analisis regresi berganda adalah, jika nilai Sig. < 0,05 maka variabel bebas berpengaruh terhadap variabel terikat dan sebaliknya, maka dapat disimpulkan bahwa tidak terdapat pengaruh perputaran kas $\left(\mathrm{X}_{1}\right)$ terhadap profitabilitas $(\mathrm{Y})$, dengan kata lain perputaran kas tidak mempunyai pengaruh yang signifikan terhadap profitabilitas.

\section{Pengujian hipotesis kedua $\left(\mathrm{H}_{2}\right)$}

Berdasarkan hasil output Uji t, diketahui nilai Sig. untuk pengaruh $\mathrm{X}_{2}$ terhadap $\mathrm{Y}$ adalah sebesar $0.044<0.05$. Dasar pengambilan keputusan Uji t Parsial dalam analisis regresi berganda adalah, jika nilai Sig. $<0,05$ maka variabel bebas berpengaruh terhadap variabel terikat dan sebaliknya, maka dapat disimpulkan bahwa terdapat pengaruh perputaran piutang $\left(\mathrm{X}_{2}\right)$ terhadap profitabilitas $(\mathrm{Y})$, dengan kata lain perputaran piutang mempunyai pengaruh yang signifikan terhadap profitabilitas.

\section{Pengujian hipotesis ketiga $\left(\mathrm{H}_{3}\right)$}

Berdasarkan output diketahui nilai signifikansi untuk pengaruh perputaran kas $\left(\mathrm{X}_{1}\right)$ dan perputaran piutang $\left(\mathrm{X}_{2}\right)$ secara simultan terhadap profitabilitas (Y) adalah sebesar $0.038<0,05$. Dasar pengambilan keputusan Uji F dalam analisis regresi berganda adalah Jika nilai Sig. $<0,05$, maka variabel bebas secara bersama-sama berpengaruh terhadap variabel terikat dan sebaliknya, jika nilai Sig. > 0,05 maka variabel bebas secara bersamasama tidak berpengaruh terhadap variabel terikat, maka dapat disimpulkan bahwa terdapat pengaruh secara signifikan antara perputaran kas $\left(\mathrm{X}_{1}\right)$ dan perputaran piutang $\left(\mathrm{X}_{2}\right)$ secara simultan terhadap profitabilitas $(\mathrm{Y})$.

\section{KOEFISIEN DETERMINASI}

Berdasarkan output diketahui nilai $R$ Square sebesar 0,981, hal ini mengandung arti bahwa berpengaruh variabel $X_{1}$ dan $X_{2}$ secara simultan terhadap variabel $\mathrm{Y}$ adalah sebesar 98,1\%. Diketahui Nilai $R$ Square diatas angka 1 maka dapat disimpulkan kemampuan variabel memberikan hampir semua informasi yang dibutuhkan untuk memprediksi variasi variabel depedent.

\section{SIMPULAN}

\section{Kesimpulan}

Dari hasil analisis data dari bab sebelumnya, maka dapat diambil kesimpulan sebagai berikut:

1. Perputaran kas dan perputaran piutang memiliki hubungan dengan profitabilitas peru- sahaan.

2. Perputaran kas tidak memiliki pengaruh yang signifikan terhadap profitabilitas perusahaan.

3. Perputaran piutang pengaruh memiliki pengaruh yang signifikan terhadap profitabilitas perusahaan

4. Perputaran kas dan perputaran piutang memiliki pengaruh yang signifikan terhadap profitabilitas perusahaan.

\section{Saran}

Dengan adanya berbagai keterbatasan yang telah disampaikan diatas dan keterbatasan peneliti dalam menggali data yang diperlukan, maka peneliti memberikan saran untuk penelitian berikutnya, antara lain yaitu sebagai berikut :

1. Untuk meningkatkan profitabilitas Perusahaan PT. Indofood Sukses Makmur Tbk maka, harus meningkatkan perputaran kas walaupun tidak nyata, dan harus meningkatkan perputaran piutang meskipun sudah nyata.

2. Pada peneliti selanjutnya, dapat mempertimbangkan dan memperluas faktor-faktor lain yang mempengaruhi profitabilitas selain perputaran kas dan piutang.

3. Pada peneliti selanjutnya disarankan harus mengecek ulang data jika terjadi variasi data yang sangat tinggi, memperluas penelitian sehingga diperoleh informasi yang lebih lengkap.

4. Jika pengelolaan perputaran kas dan perputaran piutang dilakukan lebih baik dan lebih efektif lagi oleh manajemen perusahaan maka profitabilitas yang didapatkan perusahaan akan terus mengalami peningkatan.

\section{DAFTAR PUSTAKA}

Abdullah, M. (2015). Pengaruh Perputaran Kas, perputaran persediaan dan perputaran piutang terhadap Profitabilitas. Jurnal Skripsi Politeknik Negri Sriwijaya.

Amaral, M. (2017). Pengaruh Perputaran Kas, perputaran piutang dan perputaran persediaan terhadap profitabilitas. Jurnal Skripsi Universitas Udayana.

Arianti, R. (2018). Pengaruh perputaran piutang, perputaran kas danperputaran persediaan terhadap profitabilitas PT. Ultrajaya Milk Industry \& Trading Company, Tbk Tahun 20082014. Jurnal Skripsi Universitas Pamulang.

Budiang, F. T. (n.d.). Pengaruh Perputaran Kas, perputaran piutang dan perputaran persediaan terhadap profitabilitas. Jurnal Skripsi STESIA Surabaya.

Budiansyah, O. (2015). Pengaruh Perputaran 
Kas, perputaran persediaan dan perputaran piutang terhadap Profitabilitas. Jurnal Skripsi MDP Palembang.

Hutami, R. A. (2018). Pengaruh Perputaran modal kerja, perputaran piutang dan perputaran persediaan terhadap Profitabilitas. Jurnal Skripsi Universitas Muhammadiyah Surakarta.

Julkarnain. (2012). Pengaruh Perputaran Modal Kerja, Kas, perputaran persediaan dan perputaran piutang terhadap Profitabilitas. Jurnal Skripsi Tanjung Pinang Universutas Maritim.

Lestari, A. P. (2011-2014). Pengaruh Perputaran Kas, perputaran persediaan dan perputaran piutang terhadap Profitabilitas.

Lestari, A. P. (2017). Pengaruh Perputaran Kas, Perputaran Persediaan dan Perputaran Piutang terhadap Profitabilitas. Jurnal Skripsi, 112.

Lestari, N. (2016). Pengaruh Perputaran Kas, Perputaran piutang dan Perputaran Persediaan Terhadap Profitabilitas. Jurnal Skripsi Universitas Pakuan.

N, R. (2011). Pengaruh Perputaran Piutang dan Perputaran Kas Terhadap Profitabilitas. Jurnal Penelitian, 31-41.

Nuriyani. (2017). Pengaruh Perputaran Kas, perputaran persediaan dan perputaran piutang terhadap Profitabilitas. Jurnal Skripsi Universitas Islam Attahiriyah Jakarta.

Octarry, M. (2015). Pengaruh Perputaran Kas, perputaran piutang, perputaran persediaan dan perputaran modal kerja terhadap Profitabilitas. Jurnal Skripsi STKIP PGRI Sumatera Barat.

Pangalila, N. I. (2017). Pengaruh Perputaran Kas, perputaran piutang dan perputaran persediaan terhadap Profitabilitas. Jurnal skripsi Akademi Autansi Permata Harapan Batam.

Pangesti, A. E. (2013). Pengaruh Perputaran Kas, perputaran persediaan dan perputaran piutang terhadap Profitabilitas. Jurnal Sekolah Tinggi Ilmu Ekonomi Perbanas.

Putri, \& Lucy. (2013). Pengaruh Perputaran Kas terhadap profitabilitas. Jurnal Sripsi Universitas Diponegoro.

Raharjo, S. (2014, Agustus 17). Uji Korelasi berganda dengan SPSS. Retrieved Agustus 12, 2018, from Konsistensi: https://www. konsistensi.com/2014/06/cara-uji-orelasiberganda-dengan-spss.html?m.-1

Rahayu, E. A. (2014). Pengaruh Perputaran Kas, perputaran persediaan dan perputaran piutang terhadap Profitabilitas. Jurnal Skripsi UNESA.

Rina, Y. (2008). Pengaruh perputaran piutang terhadap Profitabilitas. Jurnal Skripsi Malang Brawijaya.
Sufina, N. (2012). Pengaruh Perputaran Kas, piutang dan persediaan terhadap Profitabilitas. Jurnal Skkripsi Bali Udayana

Surya, S., Ruliana, R., \& Soetama, D. R. (2017). Pengaruh Perputaran Kas dan Perputaran Persediaan Terhadap Profitabilitas Tahun 2010-2013. Jurnal Skripsi STAN Indonesia Mandiri. 